\title{
Technological and Technical Skills of the Teaching Faculty Members in Balqa Applied University / Jordan In the Light of Comprehensive Quality Standards from the Viewpoint of a Number of Colleges Students
}

\author{
Burhan M Awad Al-Omari ${ }^{1}$, Mohammed Abu Rumman², Amal Yaseen AL Majali ${ }^{3}$ \& Ata E. M. AL Shra'ah ${ }^{2}$ \\ ${ }^{1}$ College of Administrative and Finance, Business Studies Department, The University of Jordan, Jordan \\ ${ }^{2}$ Department of Business Administration, AlBalqa Applied University, AL-Salt, Jordan \\ ${ }^{3}$ Management and Financial Science Branch, AlBalqa Applied University, Karak, Jordan \\ Correspondence: Mohammed Abu Rumman, Department of Business Administration, AlBalqa Applied \\ University, AL-Salt, Jordan. E-mail: mohammad_n_k_s@yahoo.com
}

Received: July 23, 2012

Accepted: August 17, 2012

Online Published: September 3, 2012

doi:10.5539/ibr.v5n10p154

URL: http://dx.doi.org/10.5539/ibr.v5n10p154

\begin{abstract}
The aim of this study is to determine the reality of the practices of the faculty members of teaching skills in light of comprehensive quality standards from the viewpoint of Balqa applied University College students. To achieve the objective of the study the researcher designed a questionnaire included four axes on quality standards in teaching. The study found out that the teachers of these colleges have skills associated with qualities of teaching methods, strategies, teaching methods, techniques, interaction, communication and the evaluation. But they're poor if some special skills like the inability to diversify in the initialization methods to lecture in various ways, to motivate students to learn, does not possesses the ability to provide feedback to students answers, does not support scientific and creative thinking. Never use modern teaching methods and techniques in the best way, and does not emphasize the student use of computers outside the classroom in organizing their daily duties and perform scientific tasks and scientific research. The study recommended the teachers of Applied University of Balqa colleges to increase the attention to skills associated with teaching methods and strategies, teaching methods and techniques, interaction and communication, and evaluation. Particular as regards to diversification in the initialization methods for lecture using the different available methods to stimulating students learning, such as using stories, realistic problems, current events, PowerPoint, scientific demonstration, and to develop their abilities in providing feedback to students answers and support their skills in scientific, creative and critic thinking and to use modern teaching methods and techniques, and the use of student computers outside the classroom in organizing their daily duties and perform scientific tasks and scientific research.
\end{abstract}

Keywords: technological, technical, skills, teaching, faculty, strategies, students

\section{Introduction}

The current century and specially our educational institutions in the Hashemite Kingdom see a rapid evolving in various areas of education; as a result of the information, technical and communication revolution, which calls for the development of all components of the education system and its improvement and modernization to meet under those changes. Therefore, the education reform processes has gained a considerable attention throughout the world, particularly in Jordanian education, and the TQM has the largest share of attention which leads the researchers to call this era quality era until the international and Jordanian community find that TQM and educational reform as two sides of the same coin, one can mention that TQM is the real challenge facing Nations in the coming decades (Canaan, 2003: 9). University education quality represents the most important challenges facing education systems in all the countries of the third world, particularly when the reports of the world organizations emphasizes the need to reconsider the philosophy of university education with emphasis on the importance to establish better standards to reach quality education outputs which are expected to lead to the development of the human personality to serve his society and support national culture. Studies confirm the need 
to adopt a total quality management (TQM) in the development of university education for the following reasons (Tablan, 2007: 16-17):

1. (Educational Deficit): education output cannot fulfill the demands of the labor market as required.

2. (High Rate of Unemployment): the labor market does not create the adequate and appropriate number of jobs to the educational output, particularly in some Gulf States.

3. (Production-Education Gap): This means the absence of appropriate scientific disciplines required for the occupations in the labor market.

4. (Educational Rising Cost): this may be associated with low return on education investment add to the delays in the recruitment of graduates.

Nassar (2005: 39) Confirmed that the quality of education in General and higher education in particular is considered an essential demand to achieve in our recent days with its complexity, changes and intense competition in the labor market compared to the public and private higher education institutions, and its ability to achieve the desired quality, and here we must consider and set in account to the entrance that must be adopted by the educational organizations to achieve the desired quality, So that because you cannot separated the objective from the importance to achieve it, otherwise it will remain a slogan without any meaning. There are a large number of studies aimed at the application of comprehensive quality in higher education, some of them is the study of Lewis (1997) which its results showed on need to link between the educational system and the needs of the students, with plans and teaching strategies and methods to overcome problems of higher education system, as the study also indicated that the overall standards of quality is based on commitment to the continuous improvement of the educational process, build confidence in students and encourage continued cooperation with educational process and its operators.

The total quality management in higher education institutions is represented in the following areas:

- Establish quality requirements in higher education,

- Follow-up education process and its development,

- Development of manpower,

- And finally, decision-making, and community service. (Al-Musawi: 2003) and (1997 et al., Tann) shows that in order to apply total quality system in a university educational systems, we must develop a set of principles and conditions which help to implement TQM elements, the most important ones are:

- Precise objectives,

- Relationship and link between subsystems within the educational institutions that apply system, and customer requirements,

- Considering the system, cooperation, and building curriculum,

- And finally, full awareness and knowledge of goals. (Jalhoum: 2008: 77). For this reason many of the developed countries and a large number of Arabic States gave attention the subject of quality of education, as the Hashemite Kingdom of Jordan is striving in this area like Arabic State to enable their universities to face local and global challenges facing their institutions and especially the higher education; by focusing on achieving overall quality within their administrative and academic units and to improve the quality of educational services and outputs

\section{The Objectives of the Study}

The study aimed to clarify the overall quality standards for the teaching represented by skills associated with teaching methods, strategies, education techniques, interaction, communication and evaluation. And the students' viewpoints of who much are the teachers of Aqaba University colleges in Jordan are commitment to it.

\section{The Importance of the Study}

1. Respond to recent trends which call for increased attention to the quality of university education at the higher education level.

2. Increase awareness of the importance of enhancing academic performance for the faculty through skills development and improvement in order to bring performance to the level of expected quality standards.

3. Search may provide or contribute to reconsider development of teaching practices of the faculty in the colleges of Balqa applied university. 
4. Determine the achieved quality standards in teaching practices for the faculty in the colleges of Balqa applied university.

5. Add a scientific study for studies related to teaching science subjects in its various differences.

\section{Study Methodology}

This study followed the descriptive analytical methodology, collected data from the sample survey where analyzed to get the results of the study.

\section{Study Community}

The study society is represented by the students of the College of Al-Balqa' applied University in Jordan.

\section{Sample Study}

The sample of the study consisted of a random sample consisting of 338 students from various faculties of Balqa applied University. Table1 shows a description of the personal factors of the sample, which was as follows:

- Gender: male accounted for $51.8 \%$ of the sample and $48.18 \%$ of females.

- Educational stage: that $57.10 \%$ of the sample of diploma students, $38.46 \%$ of the Bachelor's degree, and $4.44 \%$ of higher graduate studies.

- Level of education: that $30.18 \%$ of the sample are form the third year, $27.81 \%$ of fourth-year students, $24.85 \%$ of the second year, and $17.16 \%$ of first year.

- Rate of General secondary: that $32.54 \%$ their rate at the general secondary is between $66-75,31.36 \%$ ranges between $55-65$, and $21.60 \%$ between $76-85$, and $14.50 \%$ is 86 or more.

Table 1. Frequency and the percentage of respondents to personal variables

\begin{tabular}{llll}
\hline Working class frequency percentage\% & & & \\
\hline Factor & Category & Frequency & Percentage \\
\hline Gender & Male & 173 & 51.18 \\
& Female & 165 & 48.82 \\
Educational stage & diploma & 193 & 57.10 \\
& Bachelor & 130 & 38.46 \\
& graduate studies & 15 & 4.44 \\
Level of education & First year & 58 & 17.16 \\
& Second year & 84 & 24.85 \\
& Third year & 102 & 30.18 \\
Rate of General secondary & Fourth year and more & 94 & 27.81 \\
& $55-65$ & 106 & 31.36 \\
& $66-75$ & 110 & 32.54 \\
& $76-85$ & 73 & 21.60 \\
& 86 and higher & 49 & 14.50 \\
\hline
\end{tabular}

\section{The Problem of the Study}

The problem study is represented in the following question which this study aims to answer:

- The availability of comprehensive quality standards in teaching skills by teaching in Balqa applied university colleges associated with teaching methods and strategies?

- The availability of comprehensive quality standards in teaching skills by teaching in Balqa applied university colleges associated with teaching methods and techniques to be used?

- The availability of comprehensive quality standards in teaching skills by teaching in Balqa applied university colleges associated with the interaction and communication by students and members of teaching staff?

- The availability of comprehensive quality standards in teaching skills by teaching in Balqa applied university colleges associated with the evaluation?

\section{Comprehensive Quality in Teaching}

- Modern roles of the teacher in the light of the comprehensive quality standards: 
The role of the teacher in these days is no longer the producer and of information and knowledge, nor it is the role of the interpreting the explainer of the facts and theories, but became more comprehensive, it is described as the on the studies of and the local, Arabic and worldwide experiences, and the role of the user of the modern teaching strategies such as: collaborative learning, oriented discovery, and problem-solving and others, to develop and nurture the mental abilities of learners such as: creative, critic and free thinking, and the ability to link analyze, conclude and evaluated. And the well-prepared teacher in the age of knowledge, globalization and labour market competition, works hard to develop a spirit of self observation, plant moral values among his students, maintain the cultural identity and nationalism among them. He also encourages learners to love knowledge, and sustainable self learning using learning sources, and modern information technology, and looking forward to everything new. (Al Hayek and Al-Kilani, 2007: 1,400). using power point slides, Excel charts and 3-d and Web usage (Internet), and the ability to prepare download and design Web sites ,and for the teacher to participate in education and reach a level of quality through knowledge of programs (ICT) Information and Communication Technology. (Solomon, 2007: 1498, And bout the expected roles of the teacher in the future.

\section{Definition of Terms}

-Technical and teaching skills:

Mohammed Hassan Daboun defined teaching skills, Superintendent of education "you cannot do best in any profession and do it in the best way unless you are familiar with its rules and principles. And teaching process must be governed by the rules, some related to the teacher and some to the learner and some related to subject and others to the learning method and means. This is what educational psychology mostly revolves around. For example, the teacher knowledge of how to teach, and what are the things that affect teaching negatively or positively, to help him to choose the right way in teaching that suited the students and scientific material. Although there are different theories and views in this area, however, the knowledge, the full study of it and applying what is true of it benefit the teacher in teaching a lot and helps to avoid many of the mistakes many teachers fall in".

\section{Comprehensive Quality Standards}

Some see TQM as the missing thing for improving education, as education strives to achieve a high standard of living for individuals and communities through the use of comprehensive quality standards in education, unless efforts are made to achieve this, the matter will become very expensive and difficult, and what is required here is the reassessment and evaluation what is there in the is in educational organization especially in the private universities and scientific and applied colleges through full knowledge of comprehensive quality standards in all educational elements such as preparing the Teaching staff members in universities and formulating of learning objectives and providing the educational classroom climate in all educational organizations.

\section{The Definition of This Term Is to Provide into Two Chairs}

A. standards:

Lamia Abu Zeid (2007: 159) identifies it as "bottled levels or standards that are universally termed, which should be made available to measure teacher performance quantitatively, qualitatively and procedurally, and express what is expected in the teacher's performance to achieve comprehensive quality-oriented". The researcher defined standards of science education as: a group of foundations, restrictions and disciplines that are proposed by him depending on what many associations and scientific bodies specialized mainly in teaching materials of science propose, taking into account the controls that lead to modern educational trends, and what quality process required in education, these criteria or disciplines are associated with all elements of the curriculum including:

* Educational goals,

* Content,

* Educational experiences,

* Teaching methods,

* The used Teaching techniques,

* The used evaluation and the evaluation that should be used,

* Scientific material teachers, 
* Educational environment...etc, and through such controls the previous elements will be displayed to ensure the achievement of quality in higher education at the University of Balqa/Jordan.

B-TQM (Total Quality):

Alshahrani (2005) defined it as "perform the work correctly according to a set of educational standards and required specifications for upgrading the quality of educational product using the least effort and cost".

Defined by the International Organization for Standardization (ISO) (Diab, 2006: 5) "as the integration of features and characteristics of a product or service in a way that enable to meet the specific needs and requirements." TQM is also known as "achieving and mastering accuracy through continuous improvement of the enterprise" (Shihata, 2005: 54).

\section{Previous Studies}

After the researcher search some of the scientific literature in this area it is indicated that there are a large number of studies that focused on teaching for scientific articles, and those studies have varied between focus on higher education and general education, including some which was interested in scientific teaching skills, while others consider the overall quality standards. Those studies will be displayed on two axes:

\subsection{The First Dimension: Studies Addresses University Education}

Sawsan Shaker Chalabi (2005) Study entitled: comprehensive quality standards in the Arabic universities, research presented at the fifth educational Conference entitled quality of university education, Faculty of education, University of Bahrain, Bahrain. Study of Ashraf Ibrahim Al-Hadi (2005) entitled: "a proposal for improving the performance of Yemeni universities according to comprehensive quality standards", working paper presented in the Fifth Conference entitled quality of university education, Faculty of education, University of Bahrain, Bahrain. But the study of Alkhthilh (2000): its objective is to identify some actual teaching skills that are practiced by teacher on the teaching university level that he should be exercising, through the viewpoint of students of King Saud University. The results confirmed that the teacher does not reach the level of University performance to the expected degree of efficiency, due to the need to return to methods and means of academic development and improvement for many skills that lead to improved academic performance, and increase the effectiveness degree and the scientific attainment for upgrading the teaching performance. While the study of Alsh'elah and Khtaibh (2002): the aim of this study is to identify the extent to which the members of the teaching body, uses the basic teaching skills and their need for developing it from the viewpoint of graduate students in a number of disciplines. The study results showed that postgraduate evaluation of teaching practices of faculty came low and less than touchstone mark (80\%), significantly in all areas without exception, communication domain with faculty members came as follows:

- First as first rank,

- Secondly, presentation of educational material,

- Thirdly, planning of educational material,

- Fourthly planning,

- Finally the evaluation.

Finally Ahmed Al Jaber Ahmed alshrayah study (2003), entitled: "the application of performance standards and quality in information technology programs and Jordan experience”, Jordan.

\subsection{The Second Dimension: Studies on General Education}

Sherman (2004) Study: this study highlighted the extent of science teachers understanding of the national standards for science and its application through data that is accessed from the files of teacher's achievements that are presented by the them to get teaching license in Cenitacet state of USA the results of the study shows that the teachers knowledge of the frame for the science of teaching and its application has participate in applying some of the scince teaching standards related to scientific, the study of Mohand Abedallah Albaker (2001) entitled the principle and standards f TMQ in the education institutions published scientific research, Al Kiewit. And the study had found that there was a shortage of teaching practices and activities of science teachers associated with the nature of science. But the study of Abed Al'deem Abed Ahalam Ali (2000) entitled "the shortage of primary teacher in the collage of education in Al zakazeek in the light of some TMQ standard" published scientific research, education and development magazine, 20 number, eight year, Cairo and the study of (Bbd- El- khalick, et al., 1998) and its goal is to identify the reality of activities and teaching practices for the science teachers inside classes and its relation with the nature of the science itself and the study found out that 
there is a shortage in the teaching practiced and activities for the science teacher related to the nature of the science. And study of Abdul Rahman (2005): this aim to identify teaching practices of teachers of science inside classrooms, and their relationship to their perceptions about the nature of science, and the study found that there were shortcomings in the teaching practices of science teachers which reflects a lack of clear understanding of the nature of science. A study (2007) by Join M.: perform a procedure of how to use educational quality standards to improve the performance of all employees of the educational process through the identification of criteria for the use of technical education in the USA State of Michigan, the results shows the low level of performance of teachers in light of the quality standards for the use of technical tools of education, the study recommended the need to directly train teachers on appropriate educational requirements to use teaching techniques. (Hussein \& Ghada, 2007: 504). Worksheet Naga (2006): the paper has discussed the quality of authenticity and contemporary standards of teaching and its roots in Islamic culture, also discussed recent trends in teaching, the study concluded the of draw criteria for quality of teaching, and those standards were categorized into three key dimensions:

- General standards,

- Teaching position components,

- Standards relating to teaching procedures planning, implementation and evaluation.

\subsection{Comment on Previous Studies}

Through what was said, we can notice the following:

1. Previous studies mostly stressed that there was a decline in school performance, whether these scientific articles are linked to quality standards or not, or had applied or has been linked in the public or private higher education or Government.

2. Arabic studies have been linked to comprehensive quality standards applied in teaching materials of scientific-researcher's knowledge.

3. Join M. study (2007) some teaching skills in study, which is the skill using methods and teaching techniques, the result came similar to the results of most studies which emphasizes the low performance of teachers in the use of methods and techniques of education in the light of the comprehensive quality standards.

4. Naga worksheet (2006) concentrated on the teaching quality standards, and these standards have totaled to (47) standard.

5. by reviewing previous studies of researcher, particularly Arabic, which discussed the availability of teaching skills of teachers of scientific materials, especially administrative ones, we find that most of them dealt with skills teaching within its traditional framework (planning, implementation, and evaluation), whereas the researcher has to focus on operational, evolutional skills which have been practiced with learners, and he added two other dimensions represented in developing the skills of communication and interaction of teacher and student, and the modern teaching methods and techniques to be developed and used; in many multiple aspects which was thought that these dimensions should seek to make the teaching and learning process successful, and transfer the role of the teacher from direct giver or knowledge transferor to a facilitator of educational process and education through e-learning education and electronic library, it also calls for the use of modern scientific foundations for comprehensive quality standards.

6. The need to adopt standards for application in education to be relied upon in teaching science subjects in order to achieve quality education and to know to what extent educational quality has been achieved.

That study has adopted many previous studies for the study tool (questionnaire), and selecting appropriate statistical methods of data analysis.

\section{Persistence of the Tool}

To test the persistence of the tool Chronbak's alpha coefficient has been used to test persistence, through table (2), which shows the results of this test, it can be seen that:

1. Alpha value of teaching methods and strategies dimension 0.79 .

2. Alpha value of teaching methods and techniques dimension 0.82 .

3. Alpha value of interaction and communication dimension 0.69 .

4. Alpha value of evaluation dimension 0.83 .

5. Alpha value for all paragraphs 0.91 . 
Which means that there is stability in the tool where all values are greater than 0.60 .

Table 2. Results of Cronbach's alpha test

\begin{tabular}{ll}
\hline Dimension & Alpha value \\
\hline Skills associated with teaching methods and strategies & 0.79 \\
Skills associated with teaching methods and techniques & 0.82 \\
Skills associated with interaction and communication & 0.69 \\
Skills associated with evaluation & 0.83 \\
Total & 0.91 \\
\hline
\end{tabular}

\section{Testing Hypothesis}

\subsection{The First Hypothesis}

The teachers in the colleges of Balqa applied University are distinguished by their teaching methods-related to skills and strategies from the viewpoint of students.

Table 3 it shows that, with the exception of paragraphs 3, 16, 21, all other paragraphs got arithmetic mean bigger than 3.00 , and observation less than 0.05 , i.e. that all these paragraphs are statistically significant.

Table 3. Arithmetic mean, standard deviation and t value of the special observe significance level related to the: teaching methods and strategies

\begin{tabular}{|c|c|c|c|c|c|}
\hline $\begin{array}{l}\text { Paragraph } \\
\text { No. }\end{array}$ & paragraph & $\begin{array}{l}\text { Arithmetic } \\
\text { mean }\end{array}$ & $\begin{array}{l}\text { standard } \\
\text { deviation }\end{array}$ & $\begin{array}{l}\text { t } \\
\text { value }\end{array}$ & $\begin{array}{l}\text { Significance } \\
\text { observation } \\
\text { Level }\end{array}$ \\
\hline 1. & Voice clearly and diversity and his ability to adjust the words exits. & 4.53 & 0.96 & 29.25 & 0.00 \\
\hline 2. & Having control over the concepts to be taught. & 3.88 & 1.07 & 15.11 & 0.00 \\
\hline 3. & $\begin{array}{l}\text { His ability to use different styles in at the beginning of lectures } \\
\text { to stimulate student as a motivation for learning } \\
\text { (story/realistic/current events issues /PowerPoint/ practical work ...). }\end{array}$ & 2.96 & 1.45 & -0.53 & 0.60 \\
\hline 4. & Use Blackboard correctly and coordinately. & 4.20 & 0.89 & 24.62 & 0.00 \\
\hline 5. & Linking various educational positions. & 3.30 & 1.06 & 5.12 & 0.00 \\
\hline 6. & Runs and control the classroom. & 4.21 & 1.04 & 21.31 & 0.00 \\
\hline 7. & Use different teaching methods and doesn't not focus on one type. & .4 .39 & 0.89 & 28.75 & 0.00 \\
\hline 8. & Exercise science skills to help his students to acquire and use them. & 3.97 & 0.85 & 20.96 & 0.00 \\
\hline 9. & Supports self learning of his students. & 4.22 & 1.35 & 16.66 & 0.00 \\
\hline 10. & Distribute the lecture time accurately and effectively. & 4.49 & 0.71 & 38.70 & 0.00 \\
\hline 11. & Use examples and analogies to explain the lecture. & 4.10 & 0.81 & 25.01 & .0 .00 \\
\hline 12. & $\begin{array}{l}\text { Consider individual differences among students during his } \\
\text { explanation. }\end{array}$ & 3.97 & 1.12 & 16.02 & 0.00 \\
\hline 13. & $\begin{array}{l}\text { Using different learning resources: books, the Internet, projects, } \\
\text { labs, and library ... Etc. }\end{array}$ & 3.35 & 1.13 & 5.69 & .0 .00 \\
\hline 14. & $\begin{array}{l}\text { Links the curriculum to be taught with other curriculum and social } \\
\text { life. }\end{array}$ & 4.01 & 0.96 & 19.46 & 0.00 \\
\hline 15. & $\begin{array}{l}\text { Using different physical gestures and (body language) appropriately } \\
\text { during explained. }\end{array}$ & 3.90 & 1.17 & 14.20 & 0.00 \\
\hline 16. & supports thinking skills (scientific/critic/innovative ...Etc). & 3.12 & 1.16 & 1.88 & 0.06 \\
\hline 17. & $\begin{array}{l}\text { Using different kind of questions taking into account individual } \\
\text { differences. }\end{array}$ & 3.17 & 1.29 & 2.49 & 0.01 \\
\hline 18. & $\begin{array}{l}\text { Ask questions that would stimulate students to think, research and } \\
\text { survey. }\end{array}$ & 4.20 & 0.94 & 23.40 & 0.00 \\
\hline 19. & $\begin{array}{l}\text { used means of incitement to answer such as: Reframing, simplified } \\
\text { the question Etc. }\end{array}$ & 4.00 & 1.40 & 13.13 & 0.00 \\
\hline 20. & Use a variety of methods to encourage students to ask questions. & 3.54 & 1.31 & 7.53 & 0.00 \\
\hline \multirow[t]{2}{*}{21.} & Capable of providing feedback to students answers. & 2.99 & 1.32 & -0.04 & 0.97 \\
\hline & Total & 3.66 & 0.51 & 23.89 & 0.00 \\
\hline
\end{tabular}


Paragraph No. 1 concerning sound clarity and diversity and words exits adjustment, ranked first with 4.53 arithmetic mean. And paragraph 10 that measure capacity to the distribution of the lecture time carefully and effectively ranked second and with 4.49 arithmetic mean, then came the paragraphs 7, 9, 6, 4, 18, 11, 14, 19, 8, $12,2,20,13,5$, respectively. Paragraph No. 17 relating to diversification in the nature of the questions by the teacher to students taking into account individual differences, ranked last within statistically significant paragraphs with 3.17 arithmetic mean.

Paragraphs No. 3 and no. 21 obtained arithmetic mean less than 3.00, i.e. they are not statically significant, i.e. that the teacher does not vary in the methods of lecture configuration in various ways to motivate students to learn, nor does he has the ability to provide feedback to the students' answers.

Paragraph No. 16 although they got arithmetic mean greater than 3.00 but the level of significant is greater than 0.05 , i.e. it is not statistically significant; teacher does not support scientific critical and creative thinking skills.

All paragraphs combined has got 3.66arithmetic mean and level of observation less than 0.05 i.e. The first hypotheses has been accepted which means that the teachers of Balqa applied University are distinguished by their teaching methods-related to skills and strategies from the viewpoint of students.

\subsection{The Second Hypothesis}

Teachers of Balqa applied University are distinguished by their teaching methods-related to teaching techniques from the viewpoint of students.

Table 4 shows that, with the exception of paragraphs 22, 26, all other paragraphs go arithmetic mean bigger than 3.00 , and observation level less than 0.05 , i.e. that all these paragraphs are statistically significance.

Paragraph No. 24 relating to help students to take advantage of teaching techniques in the process of learning, the first rank with 3.90 arithmetic mean and Paragraph No. 27 that measure having skills using digital sources of information, ranked second and with 3.86 arithmetic mean, then paragraph No. 23 ranked third, for paragraph No. 25 related to encourage students to use the Internet to get information and scientific knowledge associated with the scientific article, ranked last within statistically acceptable paragraphs and with 3.57arithmetic mean.

Paragraphs No. 22 and No. 26 obtained arithmetic mean less than 3.00, i.e. they are not statistically significance, which means that teachers do not use modern teaching methods and techniques in the best way, and doesn't emphasizes students using computes outside the classroom in organizing daily duties and performing scientific tasks and research, and communicate with the Faculty and with the students themselves.

Table 4. Arithmetic mean, standard deviation and t value of the special observe significance level related to the: teaching techniques and strategies

\begin{tabular}{|c|c|c|c|c|c|}
\hline $\begin{array}{l}\text { Paragraph } \\
\text { No. }\end{array}$ & Paragraph & $\begin{array}{l}\text { Arithmetic } \\
\text { mean }\end{array}$ & $\begin{array}{l}\text { Standard } \\
\text { deviation }\end{array}$ & $\begin{array}{l}\text { t } \\
\text { value }\end{array}$ & $\begin{array}{l}\text { Significance } \\
\text { observation } \\
\text { Level }\end{array}$ \\
\hline 22. & $\begin{array}{l}\text { The teacher uses modern teaching methods and techniques as } \\
\text { computer (PowerPoint/Emile...). }\end{array}$ & 2.98 & 1.32 & -0.04 & 0.96 \\
\hline 23 & $\begin{array}{l}\text { Uses a variety of instructional methods and techniques in order } \\
\text { to achieve the objectives of the lecture. }\end{array}$ & 3.80 & 1.27 & 11.55 & 0.00 \\
\hline 24. & $\begin{array}{l}\text { Help students to take advantage of teaching techniques in the } \\
\text { process of learning. }\end{array}$ & 3.90 & 1.35 & 12.26 & 0.00 \\
\hline 25. & $\begin{array}{l}\text { Encourage students to use the Internet to obtain information and } \\
\text { knowledge related to the scientific material. }\end{array}$ & 3.57 & 1.15 & 9.10 & 0.00 \\
\hline 26. & $\begin{array}{l}\text { Emphasizes using students to computers outside the classroom } \\
\text { in organizing daily duties and performing scientific work and } \\
\text { scientific research, and to communicate with faculty and } \\
\text { students themselves. }\end{array}$ & 2.94 & 1.57 & -0.73 & 0.47 \\
\hline \multirow[t]{2}{*}{27.} & Have skills in using digital sources of information. & 3.86 & 1.13 & 13.95 & 0.00 \\
\hline & Total & 3.51 & 0.77 & 12.20 & 0.00 \\
\hline
\end{tabular}

All paragraphs combined has got 3.51 arithmetic mean and observation level less than 0.05 , i.e. that the second premise is accepted, which means that Teachers of Balqa applied University are distinguished by their teaching methods-related to teaching techniques from the viewpoint of students. 


\subsection{The Third Hypothesis}

Teachers of Balqa applied University are distinguished by their interaction and communication skills from the viewpoint of the students.

Table 5 shows that, with the exception of paragraphs 30and 32, all other paragraphs has got arithmetic mean bigger than 3.00 , and observation levle less than 0.05 , i.e. that all these paragraphs are statistically significance.

Table 5. Arithmetic mean, standard deviation and t value of the special observe significance level related to the: interaction and communication

\begin{tabular}{|c|c|c|c|c|c|}
\hline $\begin{array}{l}\text { Paragraph } \\
\text { No. }\end{array}$ & Paragraph & $\begin{array}{l}\text { Arithmetic } \\
\text { mean }\end{array}$ & $\begin{array}{l}\text { Standard } \\
\text { deviation }\end{array}$ & $\begin{array}{l}\text { t } \\
\text { value }\end{array}$ & $\begin{array}{l}\text { Significance } \\
\text { observation } \\
\text { Level }\end{array}$ \\
\hline 28. & $\begin{array}{l}\text { Able to manage discussions and debate with his } \\
\text { students successfully within the classroom and beyond. }\end{array}$ & 3.52 & 1.07 & 8.89 & 0.00 \\
\hline 29. & $\begin{array}{l}\text { respected the views of his students even if it is not } \\
\text { similar to his opinion. }\end{array}$ & 3.43 & 1.30 & 6.16 & 0.00 \\
\hline 30. & $\begin{array}{l}\text { Offers the opportunity for students to express their } \\
\text { scientific views and criticism freely. }\end{array}$ & 2.87 & 1.39 & -1.69 & 0.09 \\
\hline 31. & Respects lecture time. & 3.37 & 1.45 & 4.69 & 0.00 \\
\hline 32. & Cares about psychological and social needs of students. & 3.17 & 1.45 & 2.13 & 0.07 \\
\hline 33. & $\begin{array}{l}\text { Handles difficult situations or embarrassing in a } \\
\text { pedagogical manner. Handled. }\end{array}$ & 3.83 & 0.94 & 16.27 & 0.00 \\
\hline 34. & $\begin{array}{l}\text { Able to provide his students with the skills and } \\
\text { decision-making skills. }\end{array}$ & 4.39 & 0.80 & 31.95 & 0.00 \\
\hline 35. & Instills confidence in students. & 4.40 & 0.99 & 26.16 & 0.00 \\
\hline 36. & $\begin{array}{l}\text { Cares to disclose students' innovative abilities and } \\
\text { develop them. }\end{array}$ & 4.01 & 1.03 & 18.18 & 0.00 \\
\hline 37. & does not use sarcastic words that frustrate his students & 4.36 & 0.87 & 28.87 & 0.00 \\
\hline 38. & Express his positive feelings towards his students. & 4.08 & 0.81 & 24.64 & 0.00 \\
\hline 39. & Promotes positive communication among students. & 4.05 & 0.95 & 20.26 & 0.00 \\
\hline 40. & $\begin{array}{l}\text { Interested in increasing religious and moral } \\
\text { development among students. }\end{array}$ & 4.17 & .0 .99 & 21.73 & 0.00 \\
\hline \multirow[t]{2}{*}{41} & Stimulates the patriotism of his students. & 4.25 & 0.90 & 25.37 & 0.00 \\
\hline & Total & 3.85 & 0.55 & 28.34 & 0.00 \\
\hline
\end{tabular}

Paragraph No. 35 concerning the teacher ability to plant confidence in the students, ranked first and with 4.40 arithmetic mean. Paragraph No. 34, which measure the ability to provide students with the skills of making decision and act upon it, second place with 4.39 arithmetic mean , then came paragraphs No.37, 41, 40, 38, 39, $36,33,28,29$, respectively, paragraph 31 concerning respect for the lecture time, was ranked last within statistically significance paragraphs and with 3.37 arithmetic mean.

Paragraph No. 30 got arithmetic mean less than 3.00, i.e. none statistically significance, meaning that teachers do not provide opportunity for students to express their views freely and to also to criticize.

Paragraph No. 32 got arithmetic mean larger than 3.00 but the observation level is greater than 0.05 scenes, i.e. it is not statistically significance. I.e. the teachers are not interested in the psychological and social needs of students.

All paragraphs combined has got 3.85 arithmetic mean and observation level less than 0.05 , which means that the third hypothesis is accepted, Teachers of Balqa applied University are distinguished by their interaction and communication skills from the viewpoint of the students.

\subsection{Hypothesis 4}

Teachers of Balqa applied University are distinguished by their evaluation skills from the viewpoint of the students.

Table 6 shows that, with the exception of paragraph No. 45, all other paragraphs got arithmetic mean bigger than 3.00 , and observation level less than 0.05 , i.e. that all these paragraphs are statistical significance. 
Table 6. Arithmetic mean, standard deviation and t value of the special observe significance level related to evaluation

\begin{tabular}{|c|c|c|c|c|c|}
\hline $\begin{array}{l}\text { Paragraph } \\
\text { No. }\end{array}$ & Paragraph & $\begin{array}{l}\text { Arithmetic } \\
\text { mean }\end{array}$ & $\begin{array}{l}\text { Standard } \\
\text { deviation }\end{array}$ & $\begin{array}{l}\text { t } \\
\text { value }\end{array}$ & $\begin{array}{l}\text { Significance } \\
\text { observation } \\
\text { Level }\end{array}$ \\
\hline 44. & $\begin{array}{l}\text { Teacher tells students the methods that he will use in } \\
\text { evaluation in the first encounter with them. }\end{array}$ & 4.27 & 0.96 & 24.35 & 0.00 \\
\hline 45. & Tells students the evaluation criteria which he will use. & 3.06 & 1.46 & 0.71 & 0.48 \\
\hline 46. & Teacher takes into objectivity during student evaluation. & 4.36 & 0.98 & 25.43 & 0.00 \\
\hline 47. & $\begin{array}{l}\text { Using different evaluation styles and performance } \\
\text { between projects/tests/reports/ (portfolio) and note cards. } \\
\text { Etc. }\end{array}$ & 4.46 & 0.77 & 35.06 & 0.00 \\
\hline 48. & Encourage students self evaluation. & 4.16 & 0.97 & 21.94 & 0.00 \\
\hline 49. & $\begin{array}{l}\text { Focuses on higher mental levels in evaluation } \\
\text { measurement: analyze/construct/ evaluate. }\end{array}$ & 4.50 & 0.87 & 31.92 & 0.00 \\
\hline 50. & $\begin{array}{l}\text { Focuses on measuring the emotional and skills side along } \\
\text { with cognitive side. }\end{array}$ & 4.30 & 0.92 & 26.15 & 0.00 \\
\hline 51. & $\begin{array}{l}\text { Uses several types of evaluation (before/continuous/ } \\
\text { after/and final). }\end{array}$ & 4.02 & 0.84 & 43.57 & 0.00 \\
\hline \multirow[t]{2}{*}{52} & Consider feed back in the light of evaluation. & 3.96 & 1.05 & 32.66 & 0.00 \\
\hline & Total & 4.13 & 0.60 & 34.76 & 0.00 \\
\hline
\end{tabular}

Paragraph No. 49 which measure the concentration of teachers in evaluation on measuring high mental levels, which are analysis, installation, evaluation, ranked first and with 4.50arithmetic mean. Paragraph No. 47 which measure his ability to vary in the evaluation methods and performance between projects, tests, reports, alternate evaluation and note cards, ranked second with 4.46 arithmetic mean, then paragraphs No. 46, 50, 44, 48, 51, respectively, paragraph No. 52 related to teacher providing feedback in the light of the results of the evaluation, it was ranked last within statistically acceptable paragraphs and with 3.96 arithmetic mean.

Paragraph No. 45 got arithmetic mean less than 3.00, i.e. non-statistically significant, meaning that teachers do not teach students the evaluation criteria which will be used.

All paragraphs combined has got 4.13 arithmetic mean and level of observation less than 0.05 , which means that the fourth hypothesis is accepted, Teachers of Balqa applied University are distinguished by their evaluation skills from the viewpoint of the students.

\section{Results}

1. The teachers in the colleges of Balqa applied University are distinguished by their teaching methods-related to skills and strategies from the viewpoint of students the teachers are distinguished by their clearly voices and its diversity and the adjusting of the language, they know exactly the definitions of the material they teach, they use Blackboard correctly and in a coordinated way, they linking between the various educational positions ,the ability to manage and control classroom, varying teaching methods, exercise science skills and help students to acquire and use it, support self-learning, the ability to distribute lecture time carefully and effectively, using examples to explain the lecture, taking into account the individual differences among students during the lecture, the ability vary the sources of learning such as books, Internet, projects, labs, linking the material they teach with other material and with social life, varying the (body language) properly during the lecture, vary the nature of the questions given to students taking into account individual differences, the ability to ask questions that would stimulate students to think and research, use means of incitement to answer such as rephrasing the question ,simplified it or use other kind of questions, and using a variety of methods to encourage students to ask Questions.

But he lacks the capacity to vary the methods of starting the lecture in various ways to motivate students to learn, doesn't possesses the ability to provide feedback to students, and does not support answers skills and creative scientific thinking and criticize.

2. Teachers of Balqa applied University are distinguished by their teaching methods-related to teaching techniques from the viewpoint of students. He uses a variety of tools and techniques to achieve the educational goals of the lecture, and helps students to take advantage of teaching communication techniques in the process of learning, encourages students to use the Internet to get information and scientific knowledge associated with the 
article, have the skills to use the digital sources of information. But do not use modern teaching methods and techniques the best use, and doesn't emphasize the use of computers outside the classroom in organizing daily duties and performing scientific and research tasks, and communicate with the Faculty and with the students themselves.

3. Teachers of Balqa applied University are distinguished by their interaction and communication skills from the viewpoint of the students they are able to manage a discussion with his students successfully inside and outside the lecture room, he respect their opinions and the lecture time, dealing with difficult emergency or cynical situations in an appropriate way, and his ability to provide students with skills of decision-making, doesn't use cynical or sarcasm to suppress them, express his positive feelings towards his students, encourage the positive connection between each other, and between students themselves, his interest in the development religious and moral sense among students, motivating their patriotism. But they do not provide the opportunity for students to express their scientific views freely and to critics, and show no interest in the psychological and social needs of students.

4. Teachers of Balqa applied University are distinguished by their evaluation skills from the viewpoint of the students. Where they tells students the methods used in the evaluation in first meeting with them, take into account objectivity during students evaluation, vary in the methods of evaluation and performance between projects tests, reports and alternate evaluation, encourages students to self evaluation, focuses on the evaluation on measuring high mental levels and emotional skills side, in addition to cognitive side, and uses various types of evaluation (before/continuous/diagnostic / final), and is keen to provide feedback in the light of the results of the evaluation. However, teachers do not tell the students what evaluation standards they will use.

\section{Recommendations}

1. The study recommends Balqa applied university colleges teachers to increase the attention to the skills associated with teaching methods and strategies, teaching methods and techniques, interaction and communication, and evaluation. Because of its importance in increasing the effectiveness of the teaching process.

2. Balqa applied university colleges teachers should vary in the methods of starting a lecture to stimulate learning, such as recourse to a story, realistic problems, and current events, PowerPoint, and demonstration.

3. Balqa applied university colleges teachers should work develop their abilities in providing feedback to students' answers, leading to clearer information.

4. Balqa applied university colleges teachers should support their skills and creative scientific thinking and critic.

5. Balqa applied university colleges teachers should uses modern teaching means and techniques as computing (PowerPoint/Emile/multi-media).

6. Balqa applied university colleges teachers should confirm the students using of computers outside the classroom in organizing daily duties and performing scientific and research tasks, and communicate with the Faculty and with the students themselves.

7. Balqa applied university colleges teachers should give opportunity for students to express their views freely.

8. Balqa applied university colleges teachers should give attention to psychological and social needs of students.

9. Balqa applied university colleges teachers should inform school students of the evaluation standards that he will use to stimulate them to improve their performance.

\section{References}

Abdul, J, T., \& Hassan, A. (2005). Finance investment (from the viewpoint of borrowers): comparative study between Islamic banks and non-banks. Islamic studies, management science, 32(1).

Al-Alaoneh, A., \& Basol, M. (2004). A cash flow lending and investment decisions (field study: commercial banks and investment companies in Oman). administrative, 276(99).

Alhajaj, M. (1999). Middle accounting. Almareek Publishing House, part I.

Alkaleel, J. (2004). The impact of the policy of commercial banks, investment credit In Palestine. PhD, Annajah National University, graduate school.

El-Hussein, Habib. (2007). Dependence of investors in the Saudi stock market on the accounting information when making investment decisions. (unpublished MPhil). University of Jordan, Jordan. 
Laurie, Loma. (2004). Embedding quality: the challenges for higher education. Quality Assurance in Education, 12(4), 157-167. http://dx.doi.org/10.1108/09684880410561604

Lewis, R. G., \& Smith, D. H. (1997). Why Quality Improvement in Higher Education. International Journal, 1.

Nugheaha, Paul. (2001). Management in teaching \& learning process Available Online (Accessed in 2003). http://www.petra.ac.id/english/science/tqm/paper5.htm

Petros, Pashiardis. (1998). Moving towards, aquality climate of the University of Cyprus. The international Journal of Education Management, 12(1), 14-23.

Salman, S. (2003). Investment banking business cash surplus "status of some commercial banks of Jordan". administrative, 25(95).

Sashkin, M., \& Kiser, K. (1993). Total quality Management. Sanfransisco, Berett. Koeher., 511.

Shiba, S., et al. (1993). A New Amercan TQM: four practical revolutions in Management. Portland, productivity press, 27. 